\title{
ECOLOGICAL CHARACTERISTICS OF EDIFICATORS AND ASSECTATORS OF THE SOUTHERN TAIGA FORESTS OF THE CHELYABINSK REGION
}

(C) 2017

Getmanets Irina Anatolievna, doctor of biological sciences, head of General Ecology Department

Moskvina Irina Valerievna, postgraduate student of General Ecology Department

Chelyabinsk State University (Chelyabinsk, Russian Federation)

Artemenko Boris Alexandrovich, candidate of biological sciences, acting head of Theory, Methods and Management of Preschool Education Department

South Ural State Humanitarian Pedagogical University (Chelyabinsk, Russian Federation)

\begin{abstract}
The following paper deals with the phytoindication of ecotopes of spruce forests on the western slope of Mount Lipovaya within the territory of the Kusinsky District. This phytoindication was made on the basis of D.N. Tsyganov's ecological scales and with the help of «EcoScaleWin» computer software. The cenotic properties of species are estimated by their abundance in typical communities; limiting factors, ecological valence and tolerance are determined; the degree of use of ecological potencies and the efficiency of development of ecological space are estimated and the aggregate parameters of habitats are described. The vertical structure and composition of spruce stands are estimated, it is shown that Picea obovata is noted in all tiers, where Betula pendula and Pinus sylvestris are also present, but their numbers range from $10-20 \%$ of the total number of individuals in the study area. The unevenness of the distribution of the stand is noted. The ratio of the species of eco-and-coenotic groups is analyzed and it is shown that in the communities the species of the boreal and boron groups are predominated, the nemoral and meadow (including tall grass) groups contribute significantly, a small percentage belongs to the non-forest group species (wetland and plurizonal).

Biomorphological analysis revealed that the life form is stable, it is represented by a single-stem tree with different shape of the crown, which indicates the different ages of Siberian spruce. The investigated phytocenosis is attributed to the late succession communities, the late stage of restorative succession, because the dominant is a typically competitive species. The research materials can serve as a basis for plant communities and coenotic populations monitoring, for identifying of the potential species richness of phytocenoses.

Keywords: tolerance; ecological valence; ecological scales; phytoindication; edificators; assectators; ecologycenotic groups; ecotope; coenotic population; phytocenosis; spruce stand; Chelyabinsk Region; Kusinsky District; geobotanical descriptions; Mount Lipovaya.
\end{abstract}

\section{РАЗНООБРАЗИЕ КУЛЬТИВИРУЕМЫХ ГЕТЕРОТРОФНЫХ БАКТЕРИЙ, ВЫДЕЛЕННЫХ ИЗ ПОВЕРХНОСТНЫХ ВОД БУХТЫ ВОСТОК ЯПОНСКОГО МОРЯ}

(C) 2017

Голозубова Юлия Сергеевна, аспирант кафедры экологии

Бузолева Любовь Степановна, доктор биологических наук, профессор, профессор кафедры биоразнообразия и морских биоресурсов

Богатыренко Елена Александровна, кандидат биологических наук, доцент кафедры биоразнообразия и морских биоресурсов

Ким Александра Вячеславовна, аспирант кафедры экологии

Еськова Алена Игоревна, аспирант кафедры биоразнообразия и морских биоресурсов Дальневосточный федеральный университет (2. Владивосток, Российская Федераиия)

Аннотация. В данной статье рассматривается таксономический состав культивируемых гетеротрофных микроорганизмов поверхностных вод бухты Восток залива Петра Великого Японского моря. В бухте Восток общая численность гетеротрофных микроорганизмов составила 2,03-10 $0^{5} \mathrm{OE} /$ мл, что позволяет отнести эти морские воды к мезосапробным. Микроорганизмы, выделенные из данной прибрежной акватории, представлены 4 филумами. Среди культивируемых микроорганизмов доминировали представители филума Proteobacteria, на долю которых пришлось более 50\% от всего таксономического разнообразия культивируемых бактерий бухты Восток. Также были выделены бактерии филумов Bacteroidetes, Firmicutes и Actinobacteria. Taксономическое разнообразие сообщества бухты Восток было представлено 14 родами. На основании фенотипических признаков культивируемые гетеротрофные бактерии отнесены к Rhodococcus sp., Micrococcus sp., Actynomycetes sp., Bacillus sp., Sarcina sp., Pseudomonas sp., Acinetobacter sp., Arthrobacter sp., Vibrio sp., Halomonas sp., Flavobacterium sp., Acetobacter sp., Marinococcus sp., Pseudoalteromonas sp., Aeromonas sp., и Staphylococcus sp. Санитарно-показательные бактерии в данной бухте не были выявлены, что свидетельствует о незначительном антропогенном влиянии. Таким образом, бухта Восток действительно испытывает незначительный рекреационный стресс отдыхающих, что отражается на составе морского микробного сообществ.

Ключевые слова: культивируемые гетеротрофные микроорганизмы; таксономический состав; сообщество; антропогенное загрязнение; морские микроорганизмы; экологический мониторинг; Японское море; залив Петра Великого; залив Восток; санитарно-показательные микроорганизмы. 


\section{Актуальность исследований}

Результатом возрастающей антропогенной нагрузки на гидросферу являются значительные экологические изменения, происходящие в первую очередь в прибрежных акваториях. За последние годы многие акватории залива Петра Великого начали утрачивать свою былую ценность промысловых и рекреационных зон, так как прибрежные воды давно стали местом сброса загрязняющих веществ и активной хозяйственной деятельности [1]. В оценке качества морской среды микробная индикация является наиболее адекватной среди методов биологического контроля, позволяющий оценить характер загрязнения морской среды [2]. Микроорганизмы обладают высокой экологической пластичностью в силу уникальных физиолого-биохимических и генетических особенностей, обладают высокой скоростью размножения и роста и также имеют возможность трансформировать все существующие в природе органические соединения [3; 4]. Микроорганизмы, являясь звеном в пищевой цепочке, играют важную роль и определяют своим составом состав макрофитов. Многие виды микроорганизмов являются аллохтонными, привнесенными с речным стоком или органическим веществом. Однако существуют и истинно морские виды микроорганизмов, такие как Vibrio, Alcaligenes, Marinomonas и другие [5]. В поверхностных слоях океана бактерии находятся в сообществе полного состава, т.е. в этих слоях воды присутствует водоросли, создающие первичную продукцию и гетеротрофные микроорганизмы [6].

С 1990-х гг. получил развитие микробиологический контроль загрязнения вод залива Петра Великого, что было обусловлено изменением экологической ситуации в регионе [7]. В эти же годы возрос интерес к слабо загрязнённым акваториям (заливы Восток, Посьета, бухта Киевка и др.), обусловленный как научными, так и коммерческими целями.

Долгое время залив Восток считали одной из наиболее чистых акваторий, поскольку в него поступает менее $0,1 \%$ общего объема сточных вод, сбрасываемых в залив Петра Великого [8]. Часть акватории залива Восток, охраняется Государственным природным комплексным морским заказником «ЗаРазнообразие культивируемых гетеротрофных бактерий..

лив Восток»; на морской биологической станции «Восток» Института биологии моря ДВО РАН, расположенной на берегу этого залива, более 30 лет ведется изучение морской биоты залива Петра Великого. Однако, использование прибрежных зон в рекреационных целях в летнее время повышает темп поступления органических загрязняющих веществ морскую среду и приводит к появлению в морской среде микроорганизмов, не свойственные типичным морским микробным сообществам Японского моря [9; 10].

К настоящему времени, большинство микробиологических исследований бухты Восток рассматривают только сезонную изменчивость ОМЧ гетеротрофных бактерий, физиолого-трофических групп, энтеробактерий в морской воде [11-15]. Естественные флуктуации в морских биоценозах происходят непрерывно, однако, антропогенная деятельность приводит к изменению состава и структуру морских микробных сообществ. Таким образом, целью данной работы стало охарактеризовать таксономическое разнообразие культивируемых гетеротрофных бактерий, входящих в состав микробиоценоза бухты Восток.

\section{Материал и методы исследований}

Материалом для исследования послужили пробы поверхностных вод бухты Восток, отобранные в августе 2015 (рис. 1.) Пробу морской воды отбирали шприцем на глубине 15-20 см в пластиковый шприц (V=20 мл) и обрабатывали в течение 3-6 часов. Посев проб воды производился методом последовательных разведений с высевом на поверхность среды СММ (питательная среда для морских микроорганизмов) [16]. Инкубировали в течение 2-х суток при комнатной температуре, а затем производили подсчет выросших колониеобразующих единиц (КОЕ). Следующим этапом работы стало изучение фенотипических свойств полученных бактериальных изолятов. Морфологию клеток и колоний, подвижность, наличие спорообразования, физиолого-биохимические признаки, окраску по Граму, культуральные свойства учитывали в соответствии с классическими микробиологическими методами [17]. Идентификацию проводили с помощью определителя Берджи [18].

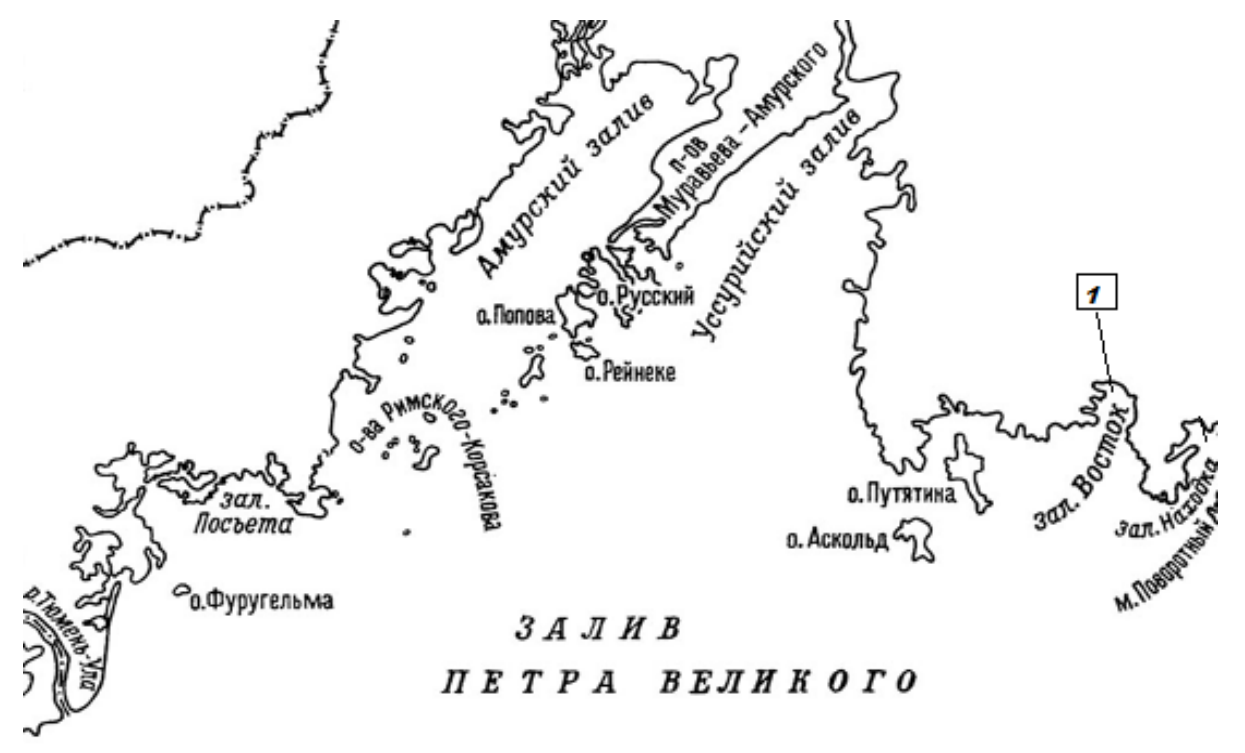

Рисунок 1 - Карта-схема района исследования. 1 - залив Восток (бухта Восток) 


\section{Результаты исследований} и их обсуждение

В бухте Восток общая численность гетеротрофных микроорганизмов составила 2,03-10 5 КОЕ/мл, что согласуется с литературными данными [8] и позволяет отнести эти морские воды к мезосапробным.

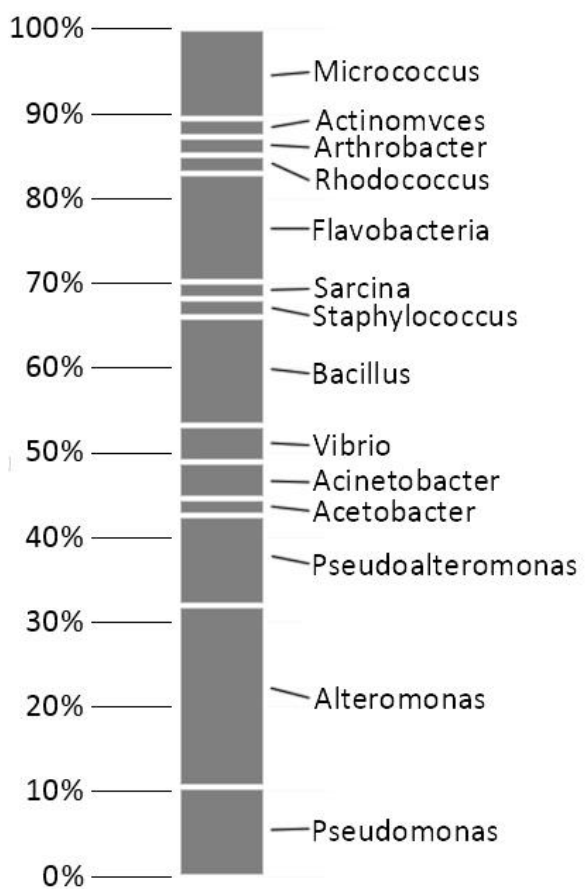

Таксономическое разнообразие сообщества бухты Восток было представлено 14 родами (рис. 2). Среди культивируемых бактерий доминировали бактерии филума Proteobacteria, на долю которых пришлось более $50 \%$ от всего биоразнообразия культивируемых бактерий бухты Восток. Также были выделены бактерии филумов Bacteroidetes, Firmicutes и Actinobacteria.

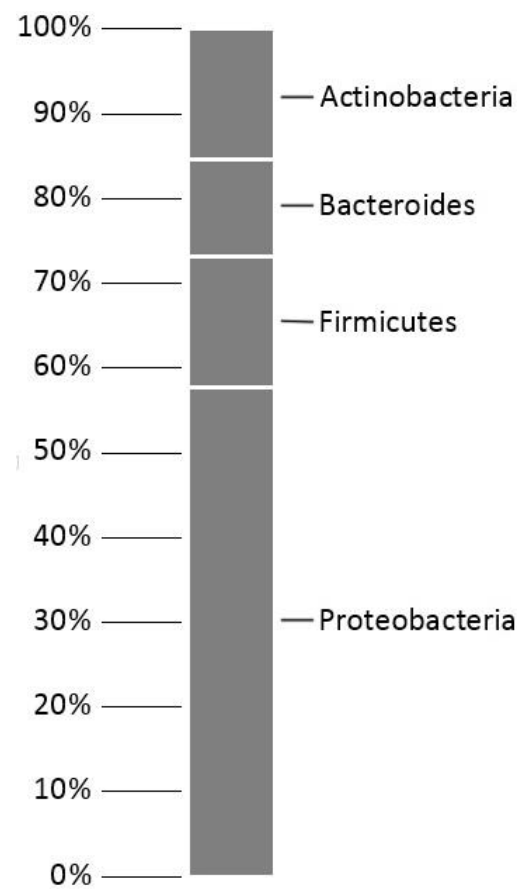

Рисунок 1 - Таксономическое разнообразие культивируемых морских микроорганизмов бухты Восток

Согласно таксономической систематики, культивируемые гетеротрофные бактерии, выделенные из бухты Восток были отнесены к отделам: Proteobacteria (Acinetobacter, Halomonas, Pseudomonas, Vibrio, Alteromonas, Pseudoalteromonas, Acetobacter), Firmicutes (Bacillus, Staphylococcus, Sarcina), Actinobacteria (Actinomyces, Rhodococcus, Micrococcus, Arthrobacter), Bacteroides - Flavobacterium.

Санитарно-показательные бактерии в данной бухте не были выявлены, что свидетельствует о незначительном уровне антропогенного пресса.

Таким образом, бухта Восток действительно испытывает незначительный рекреационный стресс отдыхающих, что отражается на составе морского микробного сообществ.

\section{Выводы}

1. Среди культивируемых бактерий доминировали бактерии филума Proteobacteria, а также были выделены бактерии филумов Firmicutes и Actinobacteria, Bacteroidetes.

2. В бухте Восток культивируемые гетеротрофные бактерии отнесены к родам Rhodococcus, Micrococcus, Actynomycetes, Bacillus, Sarcina, Pseudomonas, Acinetobacter, Arthrobacter, Vibrio, Halomonas, Flavobacterium, Acetobacter, и Marinococcus, Pseudoalteromonas, Aeromonas, Staphylococcus.

3. Бухта Восток действительно испытывает незначительный рекреационный стресс отдыхающих, что отражается на составе морского микробного сообществ и связано с отсутствием санитарно-показательных бактерий.

\section{СПИСОК ЛИТЕРАТУРЫ:}

1. Ростов И.Д., Рудых Н.И., Ростов В.И., Воронцов А.А. Тенденции климатических и антропогенных изменений морской среды прибрежных районов России в Японском море за последние десятилетия // Известия ТИНРО. 2016. Т. 186. С. 163-181.

2. Израэль Ю.А., Цыбань А.В. Антропогенная экология океана: монография. М.: Флинта наука. 2009. $520 \mathrm{c}$.

3. Цыбань А.В., Панов Г.В., Баринова С.П., Мошарова И.В. Экологические свойства и динамика гетеротрофных микроорганизмов. М.: Наука. 2000. 26 с.

4. Олейник Г.Н., Юришинец В.И., Старосила Е.В. Бактериопланктон и бактериобентос как биологические индикаторы состояния водных экосистем // Гидробиологический журнал: междунар. науч. журн. 2010. Т. 46, № 6. С. 45-70.

5. Михайлов В.В. Прокариоты = Prokaryota: [определитель]. Владивосток: Дальнаука, Биота российских вод Японского моря; Т. 2. 2004. 168 с.

6. Мишустина И.Е., Щеглова И.К., Мицкевич И.Н. Морская микробиология: учебное пособие. Владивосток: Изд-во Дальневосточного университета, 1985. $181 \mathrm{c}$.

7. Димитриева Г.Ю. Планктонные и эпифитные микроорганизмы: индикация и стабилизация состояния прибрежных морских экосистем: автореф. дис. ... д-ра биол. наук. Владивосток, 1999. 47 с.

8. Христофорова Н.К. Современное экологическое состояние залива Петра Великого Японского моря: монография. Владивосток: Изд. дом Дальневосточного федерального университета. 2012. 440 с.

9. Рубцова С.И. Гетеротрофные бактерии - показатели загрязнения и самоочищения морской среды // Экология моря. 2002. № 62. С. 81-85.

10. Бузолева Л.С., Безвербная И.П., Журавель Е.В., Калитина Е.Г. Микробиологический анализ загряз- 
нения окраинных морей северо-западной части Тихого океана // Океанология. 2006. Т. 46, № 1. С. 55-62.

11. Галышева Ю.А. Биологические последствия органического загрязнения прибрежных морских экосистем российской части Японского моря // Известия ТИНРО. 2009. Т. 158. С. 209-227.

12. Христофорова Н.К., Журавель Е.В., Миронова Ю.А. Рекреационное воздействие на залив Восток (Японское море) // Биология моря. 2002. Т. 28, № 4. C. $300-303$.

13. Бойченко Т.В. Химико-экологическая и микробиологическая оценка качества морских поверхностных вод Южного Приморья: дис. ... канд. биол. наук. Владивосток, 2009. 150 с.

14. Галышева Ю.А., Христофорова Н.К. Среда и макробентос залива Восток Японского моря в условиях рекреационного воздействия // Известия ТИНРО. 2007. Т. 149. С. 270-309.

15. Журавель Е.В., Христофорова Н.К., Дроздовская О.А., Токарчук Т.Н. Оценка состояния вод залива Восток (залив Петра Великого, Японское море) по Разнообразие культивируемых гетеротрофных бактерий..

гидрохимическим и микробиологическим показателям // Водные ресурсы. 2012. Т. 14, № 1 (9). С. 2315-2329.

16. Youchimizu M., Kimura T. Study of intestinal microflora of Salmonids // Fish. Pathol. 1976. Vol. 10, № 2. Р. 243 .

17. Винникова О.И., Самойлов А.М., Попова Ю.В. Выделение и идентификация бактерий: методические рекомендации для студентов биол. факультета специализации «Микробиология и вирусология». Харьков: ХНУ имени В.Н. Каразина, 2011. 60 с.

18. Хоулт Дж., Криг Н., Смит П. Определитель бактерий Берджи в 2-х томах: Т. 1, Т. 2. М.: Изд-во Мир. 1997. 800 с.

19. СанПиН 4631-88 «Санитарные правила и нормы охраны прибрежных вод морей от загрязнения в местах водопользования населения».

Работа выполнена при финансовой поддержке Российского научного фонда (Соглашение № 1450-00034).

\section{DIVERSITY OF CULTIVATED HETEROTROPHIC BACTERIA SELECTED FROM SURFACE WATERS OF THE VOSTOK BAY OF THE JAPANESE SEA}

(C) 2017

Golozubova Julia Sergeevna, postgraduate student of Ecology Department

Buzoleva Lyubov Stepanovna, doctor of biological sciences, professor, professor of Biodiversity and Marine Bioresources Department

Bogatyrenko Elena Aleksandrovna, candidate of biological sciences, associate professor of Biodiversity and Marine Bioresources Department

Kim Alexandra Vyacheslavovna, postgraduate student of Ecology Department

Eskova Alena Igorevna, postgraduate student of Biodiversity and Marine Bioresources Department Far Eastern Federal University (Vladivostok, Russian Federation)

Abstract. In this article, the taxonomic diversity of cultivated heterotrophic microorganisms of the surface waters of Bay Vostok of Peter the Great Bay of the Japan Sea was considered. In the bay Vostok total number of heterotrophic microorganisms was $2,03-10^{5} \mathrm{KOE} / \mathrm{ml}$ which can be attributed to mezazoprobnye sea water. Microorganisms isolated from this coastal area are represented by 4 phylums. The cultivated microorganisms were dominated by representatives of the phylum Proteobacteria, which accounted for more than $50 \%$ of the total taxonomic diversity of the cultivated bacteria of the Vostok Bay. Phylums of Bacteroidetes, Firmicutes and Actinobacteria were also isolated. The taxonomic diversity of microbial community was represented by 15 genus. Based on the phenotypic characteristics, cultured heterotrophic bacteria was classified into the genera Rhodococcus sp., Micrococcus sp., Actynomycetes sp., Bacillus sp., Sarcina sp., Pseudomonas sp., Acinetobacter sp., Arthrobacter sp., Vibrio sp., Halomonas sp., Flavobacterium sp., Acetobacter sp., and Marinococcus sp., Pseudoalteromonas sp., Aeromonas sp., Staphylococcus sp. Sanitation-indicative bacteria in this bay were not identified, which indicates a slight anthropogenic impact. Thus bay Vostok was really insignificant recreational stress and it was reflected on marine microbial community.

Keywords: cultured heterotrophic microorganisms; taxonomic composition; community; anthropogenic pollution; marine microorganisms; ecological monitoring; Sea of Japan; Gulf of Peter Great; Vostok bay; sanitary-demonstration microorganisms.

УДК 581.93

Статья поступила в редакцию 28.08.2017

\section{ФЛОРА СТУДЕНЧЕСКОГО СКВЕРА ГОРОДА ЧЕБОКСАРЫ ЧУВАШСКОЙ РЕСПУБЛИКИ} (C) 2017

Димитриев Юрий Олегович, кандидат биологических наук, доцент кафедры биоэкологии и химии Чувашский государственный педагогический университет им. И.Я. Яковлева

(г. Чебоксары, Российская Федераџия)

Аннотащия. Студенческий сквер был открыт 1 сентября 2007 г. на пересечении оживлённого Московского проспекта и улицы К. Иванова. Общая площадь 2,5 га. Преобладающими древесными породами являются Tilia cordata Mill., Betula pendula Roth и Acer platanoides L. В 2016 г. была проведена первая инвентаризация флоры сквера, выявлено 94 вида растений из 79 родов и 37 семейств. Хвойные представлены 4 культивируемыми интродуцентами. К однодольным относится только 6 видов из семейства Роасеае. Систематическое разнообразие флоры очень низкое. Практически каждый род представлен лишь одним видом. Средний уро- 